\title{
Performance evaluation of powdered activated carbon for removing 28 types of antibiotics from water
}

\author{
Xinbo Zhang ${ }^{\mathrm{a}, \mathrm{b}}$, Wenshan Guo ${ }^{\mathrm{b}}$, Huu Hao Ngo ${ }^{\mathrm{b} *}$, Haitao Wen ${ }^{\mathrm{a}}, \mathrm{Nan}^{\mathrm{c}}{ }^{\mathrm{c}}$, Wei Wu ${ }^{\mathrm{d}}$
}

${ }^{a}$ Department of Environmental and Municipal Engineering, Tianjin Key Laboratory of Aquatic Science and Technology, Tianjin Chengjian University, Jinjing Road 26, Tianjin 300384, China.

${ }^{\mathrm{b}}$ Centre for Technology in Water and Wastewater, School of Civil and Environmental Engineering, University of Technology Sydney, Sydney, NWS 2007, Australia

${ }^{\mathrm{c}}$ Department of Environmental Sciences and Engineering, Tianjin University, Wei Jin Road 92, Tianjin 300072, China.

${ }^{d}$ Tianjin Sino French Jieyuan Water Company Limited, Jieyuan Road 30, Tianjin 300121, China.

* Correspondence author: Tel: +61 29514 2745; Fax: + 61295147803 Email address: ngohuuhao121@gmail.com

\begin{abstract}
Currently, the occurrence and fate of antibiotics in the aquatic environment has become a very serious problem in that they can potentially and irreversibly damage the ecosystem and human health. For this reason, interest has increased in developing strategies to remove antibiotics from water. This study evaluated the performance of powdered activated carbon (PAC) in removing from water 6 representative groups of 28 antibiotics, namely Tetracylines (TCs), Macrolides (MCs), Chloramphenicols (CPs), Penicillins (PNs), Sulfonamides (SAs) and Quinolones (QNs). Results indicate that PAC demonstrated superior adsorption capacity for all selected antibiotics. The removal efficiency was up to $99.9 \%$ in deionized water and $99.6 \%$ in surface water at the optimum conditions with PAC dosage of $20 \mathrm{mg} / \mathrm{L}$ and contact time of 120 minutes. According to the Freundlich model's adsorption isotherm, the values of $n$ varied
\end{abstract}


among these antibiotics and most were less than 1, suggesting that the adsorption of antibiotics onto PAC was nonlinear. Adsorption of antibiotics followed well the pseudo-second-order kinetic model $\left(\mathrm{R}^{2}=0.99\right)$. Analysis using the Weber-Morris model revealed that the intra-particle diffusion was not the only rate-controlling step. Overall, the findings in this study confirm that PAC is a feasible and viable option for removing antibiotics from water in terms of water quality improvement and urgent antibiotics pollution control. Further research is essential on the following subjects: (i) removing more types of antibiotics by PAC; (ii) the adsorption process; and (iii) the mechanism of the competitive adsorption existing between natural organic matters (NOMs) and antibiotics.

Keywords: antibiotics, adsorption, powdered activated carbon, kinetics, water treatment

\section{Introduction}

In recent years, the occurrence and impacts of antibiotics in the aquatic environment have led to grave concerns about their ecological safety and health impacts given that the demand for high quality drinking water is increasing. Many studies have reported that a variety of antibiotics are present in wastewater effluents (Brown et al., 2006; Watkinson et al., 2007; Li et al., 2013; Golovko et al., 2014), surface and groundwater (Watkinson et al., 2009; Chen and Zhou, 2014; Jiang et al., 2014), some of which have even been detected in water treatment plants and drinking water supplies throughout the world (Ye et al., 2007; Yiruhan et al., 2010). The antibiotics of sulfamethoxazole, trimethoprim, and ofloxacin were detected at concentrations ranging from 110 to $470 \mathrm{ng} / \mathrm{L}$ in treated effluent at a large wastewater treatment plant (WWTP) in Albuquerque - New Mexico (Brown et al., 2006). At a WWTP in Brisbane (Australia), antibiotics (ciprofloxacin, sulphamethoxazole, lincomycin and trimethoprim) were detected in both influents and effluents with $100 \%$ frequency. Of the detected antibiotics, the concentration of ciprofloxacin was highest in influent and effluent with the mean value of $0.6 \mathrm{mg} / \mathrm{L}$ and $0.6 \mu \mathrm{g} / \mathrm{L}$, respectively (Watkinson et al., 
2007). Watkinson et al. (2009) also observed that the macrolide, quinolone and sulphonamide antibiotics were most prevalent in WWTP effluents with the concentration up to a maximum of $3.4 \mu \mathrm{g} / \mathrm{L}$. Li et al. (2013) investigated the occurrences of 22 antibiotics in a wastewater reclamation plant in Beijing (China). They discovered that quinolones were the dominant antibiotics with $4916 \mathrm{ng} / \mathrm{L}$ in influents and $1869 \mathrm{ng} / \mathrm{L}$ in secondary effluents. In the study by Golovko et al. (2014), the target compounds of 10 antibiotics were investigated in a WWTP. Specifically, these were norfloxacin, levofloxacin, ciprofloxacin, azithromycin, erythromycin, clarithromycin, trimethoprim, sulfapyridine, sulfamethoxazole, and sulfasalazine. The maximum concentrations of 10 antibiotics varied from $0.069 \mu \mathrm{g} / \mathrm{L}$ to $3.09 \mu \mathrm{g} / \mathrm{L}$ in wastewater treatment plant (WWTP)'s influents and from $0.018 \mu \mathrm{g} / \mathrm{L}$ to $2.31 \mu \mathrm{g} / \mathrm{L}$ in WWTP's effluents.

According to the study results of Watkinson et al. (2009), the antibiotics of macrolide, quinolone and sulphonamide were detected with the detection frequency of $15 \%-83 \%$ in the low ng/L range up to $2 \mu \mathrm{g} / \mathrm{L}$ in the surface waters of six investigated rivers. In addition, the mean concentrations of oxytetracycline was up to $13640.9 \mathrm{ng} / \mathrm{L}$ in surface water and $8325.8 \mathrm{ng} / \mathrm{L}$ in groundwater from the Wangyang River (China), having a detection frequency of $100 \%$ (Jiang et al., 2014). In the Huangpu River, sulfonamides indicated the highest concentrations of 34-859 $\mathrm{ng} / \mathrm{L}$ in water samples (Chen and Zhou, 2014).

In drinking waters, some antibiotics including sulfamethoxazole (3.0-3.4 ng/L), macrolides (1.4-4.9 ng/L), and quinolones (1.2-4.0 ng/L) were detected by Ye et al. (2007). Four fluoroquinolone antibiotics (norfloxacin, ciprofloxacin, lomefloxacin, and enrofloxacin) were detected in tap water at high rates in Guangzhou (77.5\%) and Macao (100\%), ranging respectively from 1.0 to $679.7 \mathrm{ng} / \mathrm{L}$ and $2.0 \mathrm{ng} / \mathrm{L}$ to $37.0 \mathrm{ng} / \mathrm{L}$ (Yiruhan et al., 2010). 
Although the concentrations of antibiotics in the aquatic environment were generally low $(\mu \mathrm{g} / \mathrm{L}$ or $\mathrm{ng} / \mathrm{L}$ level), their impact on ecosystem function and potential to endanger people's health cannot be neglected (Constanzo et al., 2005, Ahmed et al., 2015). Since antibiotics are being increasingly detected in the aquatic environment, finding efficient and effective approaches to remove them from water supplies is critical. Normally, antibiotics cannot be effectively removed (only 5\%) using conventional water treatment processes, for example coagulation, flocculation, sedimentation and filtration (Adams et al., 2002). However, they can be removed using oxidation processes such as chlorination and ozonation. Despite free chlorine, chlorine dioxide and ozone could effectively remove some antibiotics such as sulfonamides, macrolides, carbadox, and trimethoprim from surface water $(>90 \%)$, while the formation of certain oxidation by-products and their activity and toxicity still require more research (Adams et al., 2002; Westerhoff et al., 2005). Regarding membrane filtration, only nanofiltration (NF) and reverse osmosis (RO) can reject antibiotics (Snyder et al., 2007; Nghiem et al., 2005; Radjenovic et al., 2008). For instance, the concentration of trimethoprim decreased from $265 \mathrm{ng} / \mathrm{L}$ to $25 \mathrm{ng} / \mathrm{L}$ after RO treatment (Snyder et al., 2007). Sulfamethoxazole can be rejected by NF membrane with the mean value of $21 \mathrm{ng} / \mathrm{L}$ in groundwater dropping to below $2 \mathrm{ng} / \mathrm{L}$ in permeate of NF. Nevertheless, the rejection of antibiotics by NF and RO depends on the physico-chemical properties and characteristics of the membranes (Nghiem et al., 2005; Radjenovic et al., 2008).

Adsorption is another viable method for treating antibiotics. Both powdered activated carbon (PAC) and granular activated carbon (GAC) have been used to remove the selected antibiotics from water (Adams et al., 2002; Kim et al., 2010; Genç and Dogan, 2015). Based on the findings of Adams et al. (2002), the percentage removed was more than $90 \%$ for the antibiotics (carbadox, sulfachlorpyridazine, sulfadimethoxine, sulfamerazine, sulfamethazine, sulfathiazole and trimethoprim) with a PAC dosage of $50 \mathrm{mg} / \mathrm{L}$ in deionized water. Genç and Dogan (2015) found 
PAC $(0.0125 \mathrm{~g}$ in $50 \mathrm{~mL})$ removed $87 \%$ ciprofloxacin at an initial concentration of 20 $\mathrm{mg} / \mathrm{L}$ at $22{ }^{\circ} \mathrm{C}$, while $\mathrm{GAC}$ of $2 \mathrm{~g} / \mathrm{L}$ can remove more than $90 \%$ trimethoprim with an initial concentration of $50 \mathrm{mg} / \mathrm{L}$ (Kim et al., 2010).

Rivera-Utrilla et al. (2009) investigated the removal of nitroimidazole antibiotics by adsorption on activated carbon (AC), and their results showed AC could eliminate nitroimidazoles efficiently from surface and groundwater (e.g. the adsorption capacity ranging from $1.04 \mathrm{mmol} / \mathrm{g}_{\mathrm{AC}}$ to $2.04 \mathrm{mmol} / \mathrm{g}_{\mathrm{AC}}$ ). Carabineiro et al. (2012) compared the adsorption capacity of ciprofloxacin using three types of carbon-based materials (AC, carbon nanotubes and carbon xerogel). They found that the maximum adsorption capacity of $\mathrm{AC}\left(230 \mathrm{mg} / \mathrm{g}_{\mathrm{AC}}^{-1}\right)$ was much higher than the other two materials (112 and $135 \mathrm{mg} / \mathrm{g}_{\mathrm{AC}}^{-1}$ for carbon xerogel and carbon nanotubes, respectively). The removal of fluoroquinolones antibiotics such as ciprofloxacin and norfloxacin was also investigated by adsorption on microporous $\mathrm{AC}$, and results indicated that maximum removal percentages of more than $96 \%$ were achieved (Ahmed et al., 2014)

Despite the types and concentrations of antibiotics in the aquatic environment vary from place to place, the levels of some antibiotics in the surface water are very high with concentration up to $150 \mu \mathrm{g} / \mathrm{L}$ being documented in the US (Kolpin et al., 2002). As reviewed by Lapworth et al. (2012), maximum concentrations for the most commonly detected antibiotics in groundwater were reported over the $40-10^{4} \mathrm{ng} / \mathrm{L}$ range. A recent study by Ngumba et al. (2016) showed that the maximum concentration in the river waters (Kenya) of three antibiotics (sulfamethoxazole, trimethoprim, ciprofloxacin) was $13,800 \mathrm{ng} / \mathrm{L}$. Therefore it is important to investigate the occurrence of antibiotics in water sources in a certain region to: firstly, control antibiotics pollution; and secondly, treat water. Recently, Li et al. (2014) discovered that 28 selected antibiotics were prevalent in four water reservoirs in North China with the highest concentration of $73.66 \mathrm{ng} / \mathrm{L}$ (florfenicol). 
To date, although some evaluation studies on the removal of antibiotics using AC and other absorbents (e.g. zeolite, aluminum oxide, mesoporous silica spheres etc.) were carried out, only a limited number of antibiotics were involved in the investigations (Adams et al., 2002; Braschi et al., 2010; Chen and Huang, 2010; Xu et al., 2011; Gao et al., 2012; Zhang et al., 2013; Wu et al., 2013; Martucci et al., 2013; Martins et al., 2015). Moreover, the adsorption kinetic is essential to determine the rate of adsorption, especially for designing a water treatment plant. Nonetheless, only in recent times have a few studies on adsorption of antibiotics on AC focused on this problem (Kim et al., 2010; Méndez-Díaz et al., 2010; Rivera-Utrilla et al., 2013; Genç and Dogan, 2015). Hence, this study aimed to quantify the adsorptive capacity and adsorption rates of 28 selected antibiotics using PAC. The experimental data were also interpreted with kinetic and isotherms models so that the antibiotic adsorption onto PAC could be better understood.

\section{Materials and Methods}

\subsection{Chemicals and Materials}

The 28 selected antibiotics used can be divided into 6 groups, including 4 Tetracylines (TCs), 4 Macrolides (MCs), 3 Chloramphenicols (CPs), 1 Penicillins (PNs), 13

Sulfonamides (SAs), 3 Quinolones (QNs) (Table 1). Physico-chemical properties of antibiotics are listed in Table 1. Oxytetracycline, Thiamphenicol, and Kitasamycin were obtained from the Institute of Biomedical Research (China), while Chloramphenicol and Sulfapyridine derived from the Institute of Metrology (China). Others were purchased from J\&K Scientific (China). All the compounds were at least reagent grade ( $>95 \%$ purity). 
The PAC used in this study was obtained from Shanxi Xinhua Active Carbon Factory (China) with an average pore size of $3.03 \mathrm{~nm}$, specific surface area of $852.94 \mathrm{~m}^{2} / \mathrm{g}$, iodine adsorption value of $903 \mathrm{mg} / \mathrm{L}$, methylene blue adsorption of $142 \mathrm{mg} / \mathrm{L}$ and particle size of 200 mesh $(75 \mu \mathrm{m})$ (more than 95\% passing). Firstly, the PAC was washed with deionized water and then dried at $105^{\circ} \mathrm{C}$ for 2 hours and cooled to room temperature $\left(25 \pm 1^{\circ} \mathrm{C}\right)$ in the dryer. A slurry of PAC $(1000 \mathrm{mg} / \mathrm{L})$ was prepared using deionized water and stored at $4^{\circ} \mathrm{C}$, and mixed by ultrasonic oscillation for $30 \mathrm{~min}$ prior to use. The $0.45 \mu \mathrm{m}$ glass microfiber filters (Millipore, USA), were soaked for over 2 hours in $200 \mathrm{~mL}$ deionized water, and then kept at $4^{\circ} \mathrm{C}$ in the refrigerator.

Table 1 Physico-chemical properties of 28 antibiotics used in the study

\begin{tabular}{|c|c|c|c|c|c|}
\hline Group & Compound & Acronym & $\begin{array}{l}\text { Molecular } \\
\text { mass }\end{array}$ & $\log \mathrm{K}_{\mathrm{ow}}{ }^{\mathrm{a}}$ & $\mathrm{pKa}^{\mathrm{a}}$ \\
\hline \multirow[t]{4}{*}{ Tetracylines (TCs) } & Oxytetracycline & OTC & 460.45 & -0.9 & 3.27 \\
\hline & Tetracycline & $\mathrm{TC}$ & 444.43 & -1.30 & 3.3 \\
\hline & Chlortetracycline & CTC & 478.88 & -0.62 & 3.3 \\
\hline & Doxycycline & $\mathrm{DXC}$ & 444.44 & -0.02 & $\mathrm{n} / \mathrm{a}^{\mathrm{b}}$ \\
\hline \multirow[t]{4}{*}{ Macrolides (MCs) } & Erythromycin & ETM & 733.92 & 3.06 & 8.88 \\
\hline & Roxithromycin & RTM & 837.05 & 2.75 & $\mathrm{n} / \mathrm{a}^{\mathrm{b}}$ \\
\hline & Kitasamycin & KIT & 785.98 & 3.077 & $\mathrm{n} / \mathrm{a}^{\mathrm{b}}$ \\
\hline & Spiramycin & SPI & 843.05 & 1.456 & $\mathrm{n} / \mathrm{a}^{\mathrm{b}}$ \\
\hline \multirow[t]{3}{*}{ Chloramphenicols (CPs) } & Thiamphenicol & TAP & 356.22 & -0.33 & $\mathrm{n} / \mathrm{a}^{\mathrm{b}}$ \\
\hline & Florfenicol & $\mathrm{FF}$ & 358.21 & $\mathrm{n} / \mathrm{a}^{\mathrm{b}}$ & $\mathrm{n} / \mathrm{a}^{\mathrm{b}}$ \\
\hline & Chloramphenicol & CAP & 323.13 & 1.14 & $\mathrm{n} / \mathrm{a}^{\mathrm{b}}$ \\
\hline Penicillins (PNs) & Penicillin G & PNG & 373.49 & 1.83 & $\mathrm{n} / \mathrm{a}^{\mathrm{b}}$ \\
\hline \multirow[t]{13}{*}{ Sulfonamides (SAs) } & Sulfadiazine & SDZ & 250.28 & -0.09 & $6.5^{\mathrm{c}}$ \\
\hline & Sulfamerazine & SMR & 264.30 & 0.14 & $8.0^{\mathrm{c}}$ \\
\hline & Sulfamethazine & STZ & 278.33 & 0.89 & 7.59 \\
\hline & Sulfameter & ST & 280.30 & 0.41 & $\mathrm{n} / \mathrm{a}^{\mathrm{b}}$ \\
\hline & Sulfamonomethoxine & SMMX & 280.30 & 0.7 & $7.2^{\mathrm{c}}$ \\
\hline & Sulfamethizole & STL & 270.33 & 0.54 & $5.5^{\mathrm{c}}$ \\
\hline & Sulfamethoxazole & STX & 253.27 & 0.89 & $8.8^{\mathrm{c}}$ \\
\hline & Sulfamethoxypyridazine & STPD & 302.28 & $\mathrm{n} / \mathrm{a}^{\mathrm{b}}$ & $\mathrm{n} / \mathrm{a}^{\mathrm{b}}$ \\
\hline & Sulfachlorpyridazine & SCPD & 284.73 & 0.31 & $5.5^{\mathrm{c}}$ \\
\hline & Sulfacetamide & STM & 214.24 & -0.96 & 7.59 \\
\hline & Sulfapyridine & SPD & 249.29 & 0.35 & 8.43 \\
\hline & Sulfadimethoxine & SDMX & 310.33 & 1.63 & $5.9^{\mathrm{c}}$ \\
\hline & Sulfaguanidine & SPGD & 214.24 & -1.22 & 11.25 \\
\hline
\end{tabular}




\begin{tabular}{llllll} 
Quinolones (QNs) & Oxolinic acid & OLA & 261.23 & 0.94 & 6.87 \\
& Nalidixic acid & NDA & 232.23 & 1.59 & 8.6 \\
& Flumequine & FMQ & 261.25 & 1.6 & $\mathrm{n} / \mathrm{a}^{\mathrm{b}}$ \\
\hline
\end{tabular}

$\operatorname{LogK}_{\text {ow }}:$ Octanol/water partition coefficient.

pKa: Acidic equilibrium constant.

${ }^{a}$ Values obtained from U.S. National Library of Medicine: http://toxnet.nlm.nih.gov/.

${ }^{\mathrm{b}}$ Not available.

${ }^{\mathrm{c}}$ Values obtained from Li et al., 2014.

\subsection{Sampling and Sample Preparation}

The surface water $(\mathrm{pH}=7.1 \pm 0.1)$ was directly collected from Yixingbu Station in Tianjin Xinkaihe Water Treatment Plant, China. The sampling water was the mixture of 28 antibiotics spiked into the surface water, and the initial concentration of each antibiotic in all adsorption experiments was $5000 \mathrm{ng} / \mathrm{L}$.

Following collection, the water samples were filtered through $0.45 \mu \mathrm{m}$ glass microfiber filters. Sample volumes of $500 \mathrm{~mL}$ were adjusted to $\mathrm{pH} 2.0-3.0$ and to them was added $0.5 \mathrm{~g}$ disodium ethylenediamine tetraacetate ( $\left.\mathrm{Na}_{2} \mathrm{EDTA}\right)$. The target antibiotics were then concentrated through a solid phase extraction (SPE) with Oasis HLB cartridges (6 mL/500 mg, Waters, USA) and a 12 position vacuum manifold (HSE-12D). After that, antibiotics were eluted in a test tube by three $4 \mathrm{~mL}$ methanol and evaporated under nitrogen sparge. Finally, the sample was reconstituted to a final volume of $1 \mathrm{~mL}$ with $10 \%$ methanol $(\mathrm{v} / \mathrm{v})$ and transferred to an amber autosampler vial for LC-MS/MS analysis. Detailed information is documented in our previous study (Li et al., 2014). All adsorption experiments were conducted at room temperature $\left(25 \pm 1^{\circ} \mathrm{C}\right)$.

\subsection{Analytical Methods}

The LC system was an ACQUITY Ultra Performance liquid chromatography (UPLC) (Waters, Milford, USA). An ACQUITY BEH C18 (2.1 mm×50 mm i.d., $1.7 \mu \mathrm{m}$, Waters, USA) chromatograph column was employed and operated at $24^{\circ} \mathrm{C}$. The 
injection volume was $10 \mu \mathrm{L}$. Acetonitrile (phase A), ultrapure water with $0.1 \%(\mathrm{v} / \mathrm{v})$ formic acid (phase B1) and ultrapure water (phase B2) were served as mobile phases at flow-rate of $0.3 \mathrm{~mL} / \mathrm{min}$. The set-up of the gradient programs of the UPLC is shown in Tables S1 and S2.

The mass spectrometer was a Quattro Premier XE (Waters, USA) equipped with an electrospray ionization (ESI) source. The antibiotics were ionized in positive ion mode except for thiamphenicol, florfenicol and chloramphenicol which used a negative ion mode. Both positive and negative ions were acquired in the multiple reactions monitoring $(\mathrm{MRM})$ mode. The temperature of the heated capillary was $350^{\circ} \mathrm{C}$, and the source voltage was $2.8 \mathrm{kV}$. High purity nitrogen was used as the desolvation gas and the cone gas at the flow rates of $600 \mathrm{~L} / \mathrm{h}$ and $75 \mathrm{~L} / \mathrm{h}$, respectively. High purity argon was utilized as the collision gas with the collision cell pressure being $5 \times 10^{-3}$ mbar. The potential of the entrance and exit of the collision cell were set at $0 \mathrm{~V}$ and $1 \mathrm{~V}$, respectively. Target antibiotics were identified based on the precursor ion and the two most intensive product ions, together with the retention time (Table S3). Details on this have been documented elsewhere (Li et al., 2014).

\subsection{Quantification and Quality Control}

A calibration curve was generated across a wide range of concentrations $(1.5-500 \mathrm{ng} / \mathrm{L})$ with the correlation coefficients greater than 0.99 . The limits of quantifications (LOQs) were determined as signal-to-noise ratio of 10 ranging from 0.1 to $1.0 \mathrm{ng} / \mathrm{L}$. Recovery experiments with spiked samples of surface water from sampling sites were performed to determine the method's precision and accuracy. The range of recoveries was from $67.58 \%$ to $133.30 \%$, and the relative standard deviation (RSD) values ranged from $0.60 \%$ to $12.29 \%$ (in Table S4).

\subsection{Adsorption equilibrium}

The PAC of 5, 10, 15, 20, 30 and $50 \mathrm{mg} / \mathrm{L}$ was added to six $600 \mathrm{~mL}$ water samples in 1L Erlenmeyer flasks respectively. Thereafter, the samples were continuously stirred 
in the magnetic stirrer (HJ-6D, China) at speed $300 \mathrm{rpm}$. After 48-hour agitation, the samples were collected by vacuum filtration for analysis.

The adsorption capacity $q_{t}(\mathrm{ng} / \mathrm{mg})$ at time $t(\mathrm{~min})$ was computed using the following equation:

$q_{t}=\frac{\left(C_{0}-C_{e}\right) V}{M}$

where, $C_{0}(\mathrm{ng} / \mathrm{L})$ is the initial concentration of the antibiotics, $C_{e}(\mathrm{ng} / \mathrm{L})$ is the residual antibiotic concentration, $V(\mathrm{~L})$ is the volume and $M(\mathrm{mg})$ is the weight of PAC.

The antibiotics adsorptive removal efficiency $\eta(\%)$ was calculated as follows:

$\eta=\frac{C_{0}-C_{e}}{C_{0}} \times 100 \%$

The Freundlich model was applied to evaluate the adsorption isotherms (Kim et al, 2014):

$q_{e}=K_{F} C_{e}^{n}$

where, $\mathrm{q}_{\mathrm{e}}(\mathrm{ng} / \mathrm{mg})$ is the adsorption capacities at equilibrium, $\mathrm{K}_{\mathrm{F}}\left(\mathrm{ng}^{1-\mathrm{n}} \mathrm{L}^{-\mathrm{n}} \mathrm{mg}^{-1}\right)$ and $\mathrm{n}$ constitutes the Freundlich adsorption parameters.

\subsection{Adsorption kinetics}

For adsorption kinetics, six $600 \mathrm{~mL}$ water samples in 1L Erlenmeyer flask water with PAC dosage of $20 \mathrm{mg} / \mathrm{L}$ were stirred continuously at $25^{\circ} \mathrm{C}$. Water samples were collected at 10, 20, 30, 60, 120, $180 \mathrm{~min}$ from six flasks for analysis, respectively.

As the 28 selected antibiotics studied in the research belong to different types, their adsorption to PAC may reveal different removal rates. To analyze the adsorption data further, the adsorption kinetics models, such as pseudo-first order model (Eq. (4)) (Ho, 2004, 2006), pseudo-second-order model (Eq. (5)) (Ho and McKay, 1998) and Elovich model (Eq. (6)) (Ho, 2006; Aroua et al., 2008), were chosen to evaluate and explain the adsorption kinetics. In this paper, moreover, the rate-controlling step of the adsorption process was investigated with the intra-particle diffusion model (Weber 
and Morris, 1962) (Eq. (7)).

$\log \left(q_{e}-q_{t}\right)=\log q_{e}-\frac{k_{1}}{2.303} t$

where, $q_{t}(\mathrm{ng} / \mathrm{mg})$ is the adsorption capacity at time $t(\mathrm{~min}), k_{1}\left(\mathrm{~min}^{-1}\right)$ is the rate constant of pseudo-first-order adsorption.

$\frac{t}{q_{t}}=\frac{1}{k_{2} q_{e}^{2}}+\frac{1}{q_{e}} t$ and $h=k_{2} q_{e}^{2}$

where, $h(\mathrm{ng} / \mathrm{mg} \mathrm{min})$ is the initial adsorption rate, and $k_{2}(\mathrm{mg} / \mathrm{ng} \mathrm{min})$ is the pseudo second-order rate constant of adsorption.

$q_{t}=\frac{1}{\beta} \ln (\alpha \beta)+\frac{1}{\beta} \ln (t)$

where, $a$ is the initial adsorption rate $(\mathrm{ng} / \mathrm{mg} \min )$ and $\beta(\mathrm{mg} / \mathrm{ng})$ is the desorption constant.

$q_{\mathrm{t}}=K_{d} t^{1 / 2}+C$

where, $K_{d}\left(\mathrm{ng} / \mathrm{mg} \min ^{1 / 2}\right)$ is the intra-particle diffusion rate constant and values of $C$ provide a clue concerning thickness of the boundary layer.

\subsection{Effect of natural organic matters on PAC adsorption}

The adsorption experiments were conducted using both surface water and deionized water to investigate the effect of natural organic matters (NOMs) on removal of antibiotic. The concentrations of turbidity and DOC in surface water were $2.52 \pm 0.92$ NTU and $2.98 \pm 1.09 \mathrm{mg} / \mathrm{L}$, respectively. The PAC was added at a dosage of $20 \mathrm{mg} / \mathrm{L}$ and the solutions were mixed for 120 min prior to sampling. Sample analysis was conducted as described for the adsorption equilibrium and kinetics experiments. The adsorption experiments were conducted in triplicate.

\section{Results and discussion}

\subsection{Adsorption equilibrium}


The removal efficiencies of 28 antibiotics at different dosages in surface water are shown in Table 2 with the standard deviation being less than $5 \%$. Results indicated that removals of the antibiotics were enhanced by increasing PAC dosage; subsequently the removal efficiency rose from $70 \%$ to $100 \%$. However, the removal efficiencies differed slightly when PAC dosage varied from $20 \mathrm{mg} / \mathrm{L}$ to $50 \mathrm{mg} / \mathrm{L}$. Although higher PAC dosage could result in more of the antibiotics being removed, it also increased the cost of water treatment. Therefore, $20 \mathrm{mg} / \mathrm{L}$ of PAC was selected as the optimal dosage in this study for removing antibiotics from water with the adsorption capacity being greater than $220 \mathrm{ng} / \mathrm{mg}$.

\section{Table 2}

Removal efficiency of 28 antibiotics at different dosages of PAC

\begin{tabular}{|c|c|c|c|c|c|c|c|}
\hline \multirow{2}{*}{ Group } & \multirow{2}{*}{ Compound } & \multicolumn{6}{|c|}{ Removal efficiency at different dosages (\%) } \\
\hline & & $5 \mathrm{mg} / \mathrm{L}$ & $10 \mathrm{mg} / \mathrm{L}$ & $15 \mathrm{mg} / \mathrm{L}$ & $20 \mathrm{mg} / \mathrm{L}$ & $30 \mathrm{mg} / \mathrm{L}$ & $50 \mathrm{mg} / \mathrm{L}$ \\
\hline \multirow{4}{*}{$\mathrm{TCs}$} & OTC & 85.4 & 94.7 & 95.9 & 98.3 & 98.9 & 99.0 \\
\hline & TC & 89.6 & 96.4 & 97.9 & 99.2 & 99.3 & 99.4 \\
\hline & CTC & 94.9 & 97.9 & 99.1 & 99.7 & 99.8 & 99.8 \\
\hline & $\mathrm{DXC}$ & 89.6 & 96.8 & 97.4 & 98.9 & 99.2 & 99.3 \\
\hline \multirow[t]{4}{*}{ MCs } & ETM & 92.3 & 93.3 & 95.4 & 96.5 & 97.5 & 97.5 \\
\hline & RTM & 85.1 & 88.5 & 92.3 & 95.9 & 95.9 & 97.0 \\
\hline & KIT & 90.4 & 93.5 & 97.8 & 99.8 & 99.9 & 100.0 \\
\hline & SPI & 87.5 & 93.7 & 97.4 & 99.9 & 100.0 & 100.0 \\
\hline \multirow[t]{3}{*}{ CPs } & TAP & 92.6 & 95.9 & 97.1 & 99.4 & 99.4 & 99.7 \\
\hline & $\mathrm{FF}$ & 88.1 & 93.8 & 97.3 & 99.2 & 99.6 & 100.0 \\
\hline & CAP & 88.9 & 93.3 & 95.6 & 98.8 & 99.4 & 99.8 \\
\hline PNs & PNG & 76.3 & 86.4 & 91.3 & 96.8 & 99.4 & 99.5 \\
\hline \multirow[t]{8}{*}{ SAs } & SDZ & 75.9 & 80.8 & 84.9 & 91.1 & 93.9 & 96.8 \\
\hline & SMR & 80.4 & 83.9 & 88.1 & 92.8 & 96.4 & 96.9 \\
\hline & STZ & 76.9 & 84.6 & 88.1 & 95.4 & 96.9 & 98.6 \\
\hline & ST & 74.6 & 82.4 & 86.8 & 95.2 & 98.3 & 98.8 \\
\hline & SMMX & 76.9 & 82.6 & 87.5 & 93.9 & 96.2 & 96.7 \\
\hline & STL & 73.2 & 78.4 & 84.2 & 90.2 & 93.7 & 94.7 \\
\hline & STX & 72.9 & 76.0 & 81.5 & 88.0 & 90.8 & 92.1 \\
\hline & STPD & 82.6 & 90.7 & 93.1 & 98.2 & 99.2 & 99.3 \\
\hline
\end{tabular}




\begin{tabular}{|c|c|c|c|c|c|c|c|}
\hline & SCPD & 75.6 & 81.5 & 88.3 & 94.9 & 96.8 & 98.9 \\
\hline & STM & 76.5 & 80.1 & 84.3 & 89.9 & 91.0 & 92.0 \\
\hline & SPD & 81.0 & 88.2 & 93.6 & 97.8 & 98.8 & 99.0 \\
\hline \multirow{5}{*}{ QNs } & SDMX & 78.8 & 82.3 & 87.6 & 92.2 & 96.8 & 97.7 \\
\hline & SPGD & 80.7 & 89.5 & 93.6 & 97.5 & 98.9 & 99.1 \\
\hline & OLA & 93.4 & 98.5 & 99.1 & 99.9 & 100.0 & 100.0 \\
\hline & NDA & 72.5 & 88.1 & 90.8 & 98.6 & 99.5 & 99.9 \\
\hline & FMQ & 82.1 & 93.4 & 96.9 & 99.6 & 100.0 & 100.0 \\
\hline
\end{tabular}

The parameters of the Freundlich model are given in Table S5. The Freundlich model was fitted to the adsorption data with $\mathrm{R}^{2}>0.9$, and could reasonably describe the adsorption of antibiotics onto PAC. According to the results of the adsorption isotherm, most values of $\mathrm{n}$ were less than 1, which suggests the adsorption of antibiotics onto PAC was nonlinear and heterogeneous. The values of $\mathrm{n}$ obtained varied from the different antibiotics, possibly because the moieties of the adsorbate molecule influencing the adsorption of different antibiotics onto PAC (Kim et al, 2014)

\subsection{Adsorption kinetics}

Previous studies have reported that hydrolysis of most studied antibiotics either does not occur or has a half-life of more than 16 hours under typical environmental conditions $\left(\mathrm{pH}=6.0-8.5\right.$; temperature $\left.=20-25^{\circ} \mathrm{C}\right)($ Loftin et al., 2008; Białk-Bielin'ska et al., 2012). Consequently, these 28 antibiotics remained hydrolytically stable under current experimental conditions and could mainly be removed by PAC adsorption. Fig. 1 depicts the removal percentage changes of antibiotics with contact time. Results showed that the concentrations of 28 selected antibiotics decreased rapidly during the first $10 \mathrm{~min}$, and more than $70 \%$ of each antibiotic was removed. Afterwards, the adsorption rate fell while the concentration of antibiotics decreased slowly. Correspondingly, the adsorption capacity was up to $249 \mathrm{ng} / \mathrm{mg}$ and $250 \mathrm{ng} / \mathrm{mg}$ at 120 min and $180 \mathrm{~min}$, respectively. From 120 to $180 \mathrm{~min}$, the residual concentrations of antibiotics did not change except that the removals of SMR, STL, STX and SDMX 
were slightly better at $180 \mathrm{~min}$. Therefore, the results suggested that $120 \mathrm{~min}$ was suitable contact time for the antibiotic adsorption to PAC.

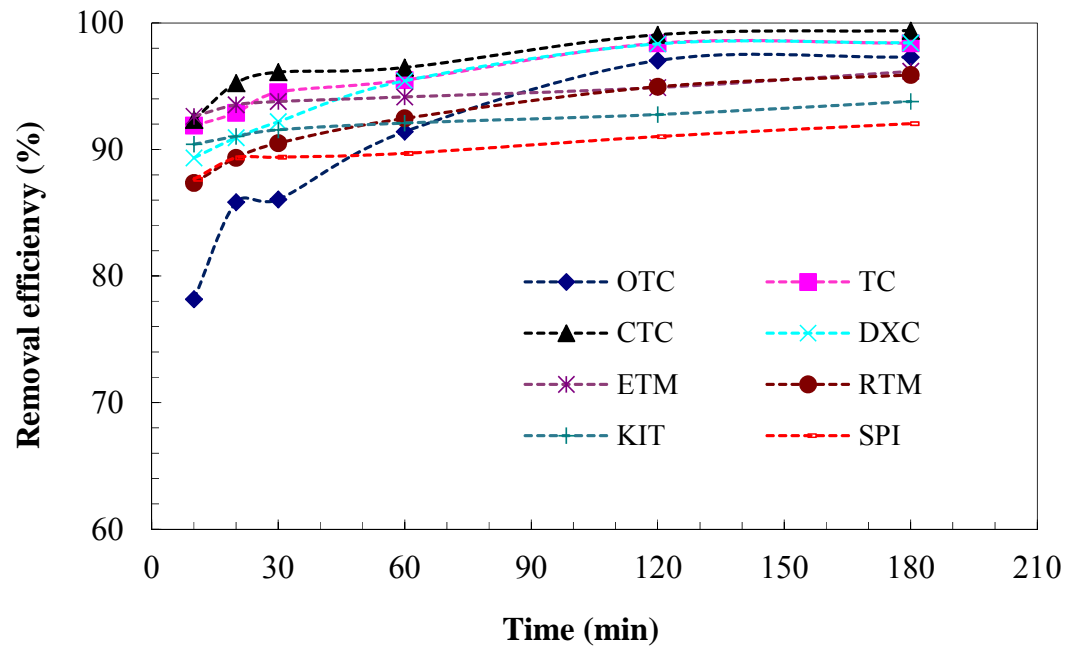

a. Removal efficiency of OTC, TC, CTC, DXC, ETM, RTM, KIT and SPI

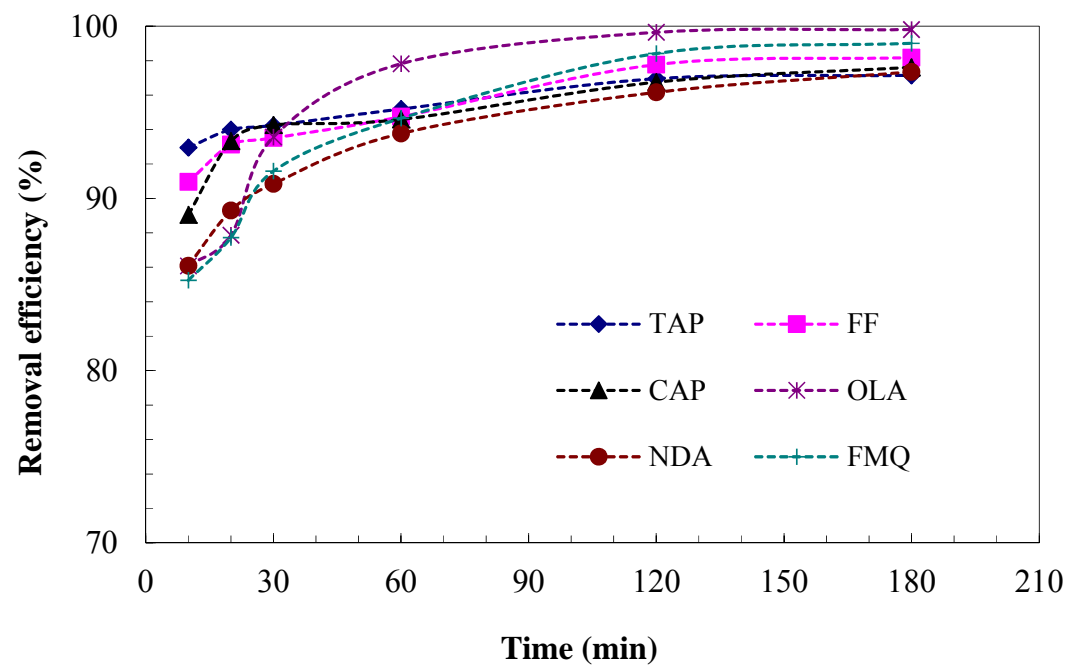

b. Removal efficiency of TAP, FF, CAP, OLA, NDA and FMQ 


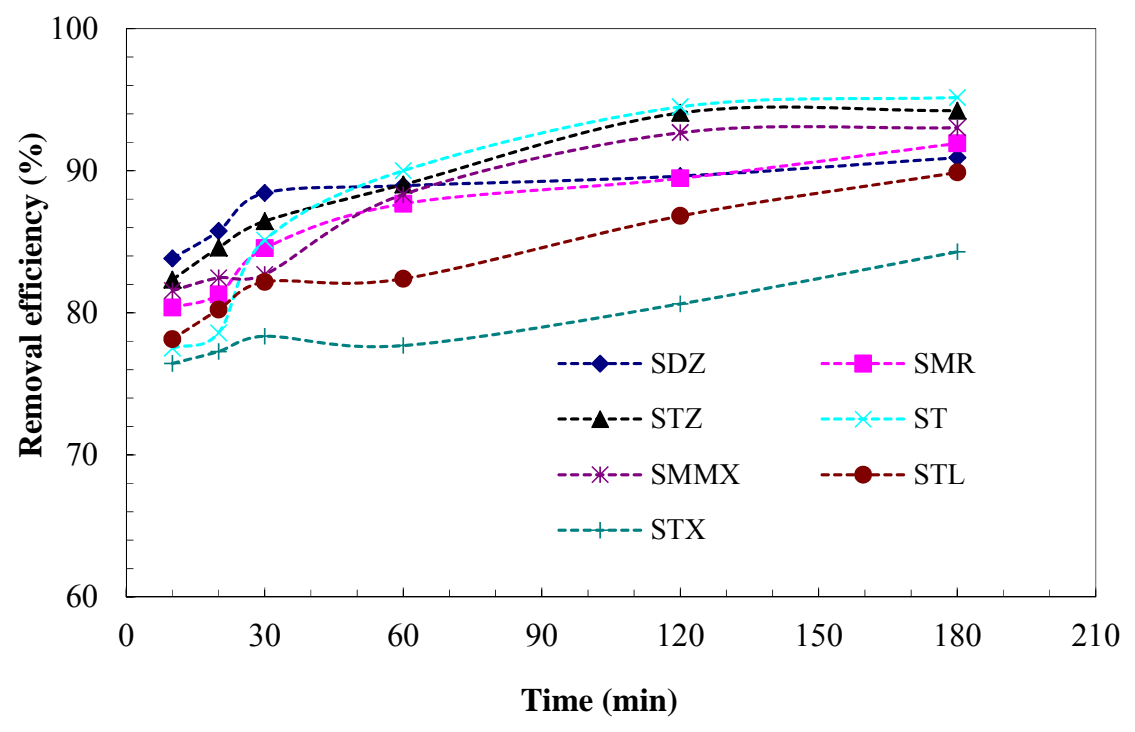

c. Removal efficiency of SDZ, SMR, STZ, ST, SMMX, STL and STX

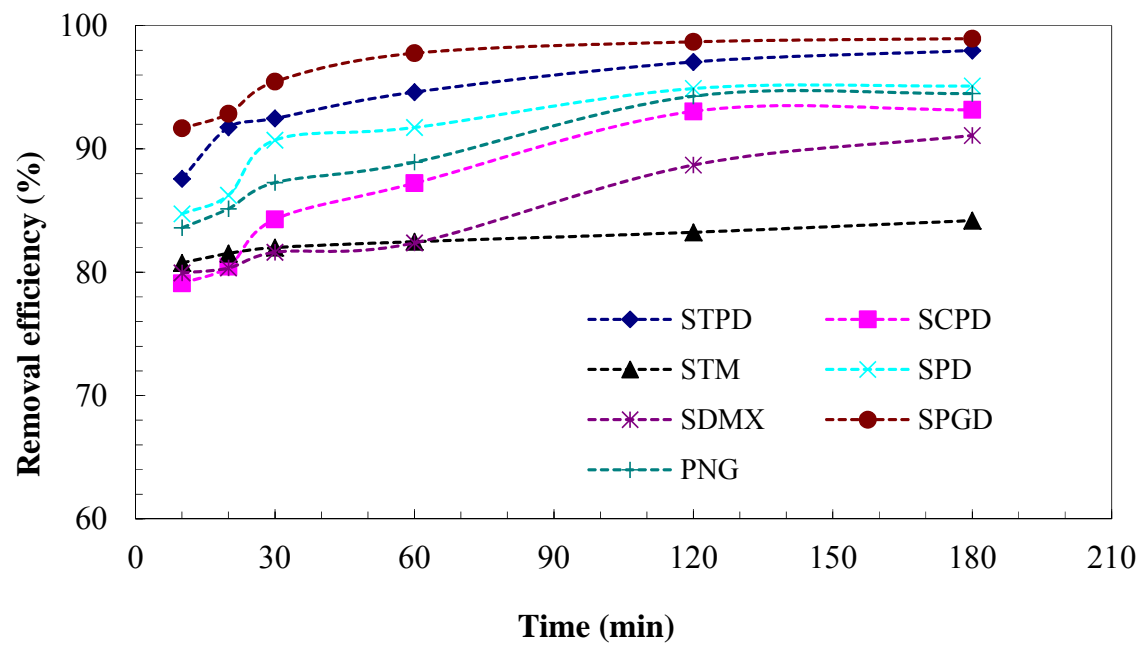

d. Removal efficiency of STPD, SCPD, STM, SPD, SDMX, SPGD and PNG

Fig.1. Removal efficiency of 28 selected antibiotics versus contact time at PAC dosage of $20 \mathrm{mg} / \mathrm{L}$

All kinetic parameters and correlation coefficients $\mathrm{R}^{2}$ are summarized in Table S6. As can be seen from Table S6, the values of $\mathrm{R}^{2}$ were very low based on the pseudofirst-order model and the experimental $\mathrm{q}_{\mathrm{e}}$ values differed greatly from the corresponding values derived from the equation. Hence, the adsorption of antibiotics onto PAC did not follow the pseudo-first-order model, which suggested that the 
external diffusion was not the determining step in the adsorption process. Conversely, the adsorption kinetics data fitted well with both the pseudo-second-order and Elovich models according to $\mathrm{R}^{2}$ values. Moreover, the second-order model indicated significantly higher $\mathrm{R}^{2}$ values (0.9989-0.9999), as well as better consistency of the experimental and theoretical $\mathrm{q}_{\mathrm{e}}$ values when compared to the pseudo-first-order and Elovich models. Thus, the antibiotics adsorption can be simulated more appropriately by the pseudo-second-order kinetic model, which indicated that chemisorption controlled the adsorption (Aroua et al., 2008). Additionally, although the Elovich model is an empirical equation and does predict any definite mechanism, it is useful in describing adsorption rate and the concentration changes. As the Elovich constant $\alpha$ can represent the initial rate of adsorption, MCs and CPs demonstrated higher initial adsorption (up to $87 \%$ and $89 \%$, respectively) than other groups of antibiotics at the beginning of the kinetic experiments due to their higher $\alpha$ values. The rate-controlling step affecting the kinetics of adsorption was analyzed by the intra-particle diffusion model (Weber-Morris). Generally, the adsorption process includes three steps: the external surface adsorption; the gradual equilibrium stage with intra-particle diffusion dominating; and a final equilibrium stage with the intra-particle diffusion starting to slow down. If the plot $\mathrm{q}_{\mathrm{t}}$ compared with $\mathrm{t}^{1 / 2}$ has a zero intercept $(\mathrm{C}=0)$, the intra-particle diffusion is an important controlling factor in determining the kinetics of the process (Rauthula and Srivastava, 2005; Aroua et al., 2008). According to Table S6, obtained high C values varying from 182.38 to 229.86 suggested the intra-particle diffusion was not the predominant mechanism. Therefore, both external and intra-particle diffusion controlled the adsorption process of antibiotics onto PAC.

\subsection{Performance of PAC adsorption under two water scenarios}

The results of the PAC adsorption experiments showed that the percentage removals of 28 selected antibiotics ranged from 96.5 to $99.9 \%$ and 86.8 to $99.6 \%$ in deionized water and surface water, respectively (Table 3). Under the surface water scenario, to a small extend the removal efficiency declined. This could be explained by the NOMs 
in surface water competing for adsorption sites (direct site competition) and/or hindered diffusion of the antibiotics into carbon pores (pore blockage/constriction) (Ando et al., 2010), which reduced the antibiotics' adsorption capacity.

Furthermore, the removal of SAs decreased more than other antibiotics, which indicated NOMs in surface water exerted a greater influence on the removal of SAs. NOMs consist of a mixture of humic substances, polysaccharides, aminosugars, proteins, peptides, lipids, small hydrophilic acids, and others (Matsui et al., 2012). The humic substances are the main fractions of NOMs in natural surface water which consist of three major functional groups, these being carboxyl, methoxyl and phenolic hydroxyl, whereas all SAs possess amino and sulfonamide groups (Bajpai et al., 2000). It is probable that the carboxyl group of NOM interacted with the SAs amino group which in turn affected the adsorption of SAs onto PAC. However, the adsorption competition mechanisms between NOM and antibiotics are complex and need further research. Overall, PAC could adsorb more than $217 \mathrm{ng} / \mathrm{mg}$ for the six groups of 28 selected antibiotics under deionized and surface water scenario at a PAC dosage of $20 \mathrm{mg} / \mathrm{L}$ and $120 \mathrm{~min}$.

\section{Table 3}

The removal efficiency of 28 antibiotics by PAC in deionized water and surface water

\begin{tabular}{|c|c|c|c|}
\hline \multirow{2}{*}{ Group } & \multirow{2}{*}{ Compound } & \multicolumn{2}{|c|}{ Removal efficiency (\%) } \\
\hline & & deionized water & surface water \\
\hline \multirow[t]{4}{*}{ TCs } & OTC & 99.8 & 97.6 \\
\hline & $\mathrm{TC}$ & 99.9 & 99.0 \\
\hline & CTC & 99.9 & 99.5 \\
\hline & $\mathrm{DXC}$ & 99.9 & 98.5 \\
\hline \multirow[t]{4}{*}{ MCs } & ETM & 99.8 & 96.3 \\
\hline & RTM & 99.9 & 95.1 \\
\hline & KIT & 99.9 & 99.6 \\
\hline & SPI & 99.8 & 91.7 \\
\hline \multirow[t]{3}{*}{ CPs } & TAP & 98.9 & 98.4 \\
\hline & $\mathrm{FF}$ & 99.2 & 98.5 \\
\hline & CAP & 99.2 & 98.4 \\
\hline PNs & PNG & 99.9 & 96.2 \\
\hline
\end{tabular}




\begin{tabular}{llll}
\hline SAs & SDZ & 99.6 & 97.5 \\
& SMR & 99.7 & 90.6 \\
& STZ & 99.8 & 94.6 \\
ST & 99.9 & 95.5 \\
& SMMX & 99.9 & 93.6 \\
& STL & 99.8 & 90.8 \\
& STX & 99.8 & 86.8 \\
& STPD & 99.9 & 97.2 \\
& SCPD & 99.9 & 93.2 \\
& STM & 98.0 & 87.0 \\
& SPD & 99.8 & 96.8 \\
& SDMX & 99.9 & 89.3 \\
QNs & SPGD & 96.5 & 96.9 \\
& OLA & 99.9 & 99.4 \\
& NDA & 99.7 & 98.4 \\
& FMQ & 99.9 & 98.7 \\
\hline
\end{tabular}

\subsection{Comparisons of the antibiotics' adsorption performance}

In this study, PAC exhibited a high adsorption capacity for 28 selected antibiotics. Based on the literature, the adsorption performance of various adsorbents was compared for these 28 antibiotics (Table 4). It can be seen that PAC has a high removal efficiency ranging from 65 to $100 \%$ at a dosage of $20 \mathrm{mg} / \mathrm{L}$ and more than $90 \%$ at a dosage of $50 \mathrm{mg} / \mathrm{L}$, respectively. Furthermore, some other adsorbents such as zeolite, mesoporous silica spheres, aluminum oxide and graphene oxide have been used to remove the antibiotics, and demonstrated different levels of removal efficiency. For example, Braschi et al. (2010) reported that zeolite had the maximal adsorption capacity of approximately $15.1 \%$ zeolite dry weight for SCPD removal. The rattle-type magnetic mesoporous silica spheres exhibited the adsorption capacity of $0.034 \mathrm{mmol} / \mathrm{g}$ and $0.079 \mathrm{mmol} / \mathrm{g}$ for STZ and TC, respectively (Xu et al., 2011). Aluminum oxide could remove $43 \%$ TC while graphene oxide could reject more than 71.4\% TC and OTC from water (Chen and Huang, 2010; Gao et al., 2012). However, since these adsorbents were only employed to remove single or binary antibiotics, the feasibility of them removing other groups of antibiotics has not yet been confirmed, and more research is needed. Furthermore, considering the antibiotic types, the 
adsorbents' dosages and experimental conditions, although it is difficult to make a fair evaluation through the data shown in Table 4, PAC can function as a good adsorbent for removing antibiotics without toxically active products compared to other absorbents, for example aluminum oxide (Chen et al., 2010; Rivera-Utrilla et al., 2013). 


\section{Table 4}

The removal efficiency or adsorption capacity of antibiotics with various adsorbents

\begin{tabular}{|c|c|c|c|c|c|}
\hline Antibiotics & Absorbent & Water type & Adsorbent dosage & $\begin{array}{l}\text { Removal efficiency or adsorption } \\
\text { capacity }\left(\mathrm{q}_{\mathrm{e}}\right)\end{array}$ & Reference \\
\hline \multirow[t]{6}{*}{ SCPD } & PAC & Surface water & 10,20 , and $50 \mathrm{mg} / \mathrm{L}$ & $10 \mathrm{mg} / \mathrm{L}: 49-73 \%$ & Adams et al. (2002) \\
\hline & & & & $20 \mathrm{mg} / \mathrm{L}: 65-100 \%$ & \\
\hline & & & & $50 \mathrm{mg} / \mathrm{L}:>90 \%$ & \\
\hline & $\begin{array}{l}\text { A highly dealuminated faujasite } \\
\text { zeolite }(\mathrm{Y})\left(200 \mathrm{SiO}_{2} / \mathrm{Al}_{2} \mathrm{O}_{3} \text { ratio }\right)\end{array}$ & Water & $\begin{array}{l}\text { a zeolite: antibiotic solution ratio of } \\
1 \mathrm{mg}: 2 \mathrm{~mL} \text {. }\end{array}$ & $>90 \%$ & Braschi et al. (2010) \\
\hline & A high silica mordenite & Distilled water & $\begin{array}{l}\text { Mordenite added with a zeolite: } \\
\text { antibiotic solution ratio of } 1 \mathrm{mg}: 2 \mathrm{~mL} \text {. }\end{array}$ & $\begin{array}{l}\text { Maximal adsorption capacity of about } \\
15.1 \% \text { zeolite dry weight }\end{array}$ & Martucci et al. (2013) \\
\hline & PAC & Surface water & $20 \mathrm{mg} / \mathrm{L}$ & $93.2 \%, \mathrm{q}_{\mathrm{e}}: 235 \mathrm{ng} / \mathrm{mg}$ & This work \\
\hline \multirow[t]{4}{*}{ STX } & PAC & Natural water & $5 \mathrm{mg} / \mathrm{L}$ & About $35 \%$ & Snyder et al. (2007) \\
\hline & Carbon nanotubes & Distilled water & $40 \mathrm{mg} / \mathrm{L}$ & $\mathrm{q}_{\mathrm{e}}: 62.8 \mathrm{mg} / \mathrm{g}$ & Tian et al. (2013) \\
\hline & Waste based carbon & Ultrapure water & $2.0 \mathrm{~g} / \mathrm{L}$ & $\mathrm{q}_{\mathrm{e}}>110 \mathrm{mg} / \mathrm{g}$ & Calisto et al. (2015) \\
\hline & PAC & Surface water & $20 \mathrm{mg} / \mathrm{L}$ & $86.8 \%$ & This work \\
\hline \multirow[t]{2}{*}{ SPD } & Carbon nanotubes & Distilled water & $40 \mathrm{mg} / \mathrm{L}$ & $\mathrm{q}_{\mathrm{e}}: 82.4 \mathrm{mg} / \mathrm{g}$ & Tian et al. (2013) \\
\hline & PAC & Surface water & $20 \mathrm{mg} / \mathrm{L}$ & $96.8 \%$ & This work \\
\hline \multirow[t]{5}{*}{ STZ } & PAC & Surface water & 10,20 , and $50 \mathrm{mg} / \mathrm{L}$ & $10 \mathrm{mg} / \mathrm{L}: 49-73 \%$ & Adams et al. (2002) \\
\hline & & & & $20 \mathrm{mg} / \mathrm{L}: 65-100 \%$ & \\
\hline & & & & $50 \mathrm{mg} / \mathrm{L}:>90 \%$ & \\
\hline & $\begin{array}{l}\text { A highly dealuminated faujasite } \\
\text { zeolite }(\mathrm{Y})\left(200 \mathrm{SiO}_{2} / \mathrm{Al}_{2} \mathrm{O}_{3} \text { ratio }\right)\end{array}$ & Water & $\begin{array}{l}\text { a zeolite: antibiotic solution ratio of } \\
1 \mathrm{mg}: 2 \mathrm{~mL}\end{array}$ & $>90 \%$ & Braschi et al. (2010) \\
\hline & $\begin{array}{l}\text { rattle-type magnetic mesoporous } \\
\text { silica spheres }\end{array}$ & $\begin{array}{l}\text { Deionized } \\
\text { Ultrapure water }\end{array}$ & $0.002 \mathrm{~g} \gamma-\mathrm{Fe}_{2} \mathrm{O}_{3} / \mathrm{mSiO}_{2}$ spheres & $\mathrm{q}_{\mathrm{e}}: 0.0342 \mathrm{mmol} / \mathrm{g}$ & Xu et al. (2011) \\
\hline
\end{tabular}




\begin{tabular}{|c|c|c|c|c|c|}
\hline & $\mathrm{PAC}$ & Surface water & $20 \mathrm{mg} / \mathrm{L}$ & $94.6 \%, \mathrm{q}_{\mathrm{e}}: 238 \mathrm{ng} / \mathrm{mg}$ & This work \\
\hline \multirow[t]{7}{*}{$\mathrm{TC}$} & Aluminum oxide & Water & $0.8-3.5 \mathrm{~g} / \mathrm{L}$ of $\mathrm{Al}_{2} \mathrm{O}_{3}$ & $43 \%$ & Chen and Huang (2010) \\
\hline & $\begin{array}{l}\text { Rattle-type magnetic mesoporous } \\
\text { silica spheres }\end{array}$ & $\begin{array}{l}\text { Deionized } \\
\text { ultrapure water }\end{array}$ & $0.002 \mathrm{~g} \gamma-\mathrm{Fe}_{2} \mathrm{O}_{3} / \mathrm{mSiO}_{2}$ spheres & $\mathrm{q}_{\mathrm{e}}: 0.0791 \mathrm{mmol} / \mathrm{g}$ & Xu et al. (2011) \\
\hline & Graphene oxide (GO) & Water & $0.544 \mathrm{mg} / \mathrm{mL} \mathrm{GO}$ stock solution & $\begin{array}{l}>71.4 \% \text {, the ideal maximum adsorption } \\
\text { capacity of } 313 \mathrm{mg} / \mathrm{g}\end{array}$ & Gao et al. (2012) \\
\hline & $\mathrm{BSA} / \mathrm{Fe}_{3} \mathrm{O}_{4}$ microspheres & Ultrapure water & $\begin{array}{l}\mathrm{BSA} / \mathrm{Fe}_{3} \mathrm{O}_{4} \text { microspheres }(200 \mathrm{mg}) \\
\text { added into } 100 \mathrm{~mL} \text { of solution }\end{array}$ & $92.07 \%$ & Zhang et al. (2013) \\
\hline & $\begin{array}{l}\text { Carbon nanoparticles made from } \\
\text { vine woo }\end{array}$ & Distilled water & $0.4 \mathrm{~g} / \mathrm{L}$ & $74-88 \%$ & $\begin{array}{l}\text { Pouretedal and Sadegh } \\
\text { (2014) }\end{array}$ \\
\hline & $\mathrm{NaOH}$-activated carbon & Distilled water & $25 \mathrm{mg} / 50 \mathrm{~mL}$ & $70-100 \%$ & Martins et al. (2015) \\
\hline & PAC & Surface water & $20 \mathrm{mg} / \mathrm{L}$ & $99.0 \%, \mathrm{q}_{\mathrm{e}}: 247 \mathrm{ng} / \mathrm{mg} .1$ & This work \\
\hline \multirow[t]{3}{*}{ OTC } & Aluminum oxide & Water & $0.8-3.5 \mathrm{~g} / \mathrm{Lof} \mathrm{Al}_{2} \mathrm{O}_{3}$ & $43-57 \%$ & Chen et al. (2010) \\
\hline & Graphene oxide & Water & $0.544 \mathrm{mg} / \mathrm{mL} \mathrm{GO}$ stock solution & $\begin{array}{l}>71.4 \% \text {, the ideal maximum adsorption } \\
\text { capacity of } 212 \mathrm{mg} / \mathrm{g}\end{array}$ & Gao et al. (2012) \\
\hline & $\mathrm{PAC}$ & Surface water & $20 \mathrm{mg} / \mathrm{L}$ & $97.6 \%, \mathrm{q}_{\mathrm{e}}: 244 \mathrm{ng} / \mathrm{mg}$ & This work \\
\hline \multirow[t]{2}{*}{$\mathrm{NDA}$} & $\begin{array}{l}\text { Montmorillonite }(\mathrm{SAz}-1) \text { and } \\
\text { kaolinite }(\mathrm{KGa}-1 \mathrm{~b})\end{array}$ & Deionized water & $\begin{array}{l}0.1 \mathrm{~g} \text { of clay and } 20.0 \mathrm{~mL} \text { of } \mathrm{NDA} \\
\text { solution }\end{array}$ & $\mathrm{q}_{\mathrm{e}}: 1.11$ and $0.9 \mathrm{mg} / \mathrm{g}$, respectively & Wu et al. (2013) \\
\hline & $\mathrm{PAC}$ & Surface water & $20 \mathrm{mg} / \mathrm{L}$ & $98.4 \%, \mathrm{q}_{\mathrm{e}}: 246 \mathrm{ng} / \mathrm{mg}$ & This work \\
\hline SDMX & PAC & Surface water & 10,20 , and $50 \mathrm{mg} / \mathrm{L}$ & $\begin{array}{l}10 \mathrm{mg} / \mathrm{L}: 49-73 \% \\
20 \mathrm{mg} / \mathrm{L}: 65-100 \% \\
50 \mathrm{mg} / \mathrm{L}:>90 \%\end{array}$ & Adams et al. (2002) \\
\hline SMR & $\begin{array}{l}\text { PAC } \\
\text { PAC }\end{array}$ & $\begin{array}{l}\text { Surface water } \\
\text { Surface water }\end{array}$ & $\begin{array}{l}20 \mathrm{mg} / \mathrm{L} \\
10,20 \text {, and } 50 \mathrm{mg} / \mathrm{L}\end{array}$ & $\begin{array}{l}89.3 \%, \mathrm{q}_{\mathrm{e}}: 233 \mathrm{ng} / \mathrm{mg} \\
10 \mathrm{mg} / \mathrm{L}: 49-73 \% \\
20 \mathrm{mg} / \mathrm{L}: 65-100 \%\end{array}$ & $\begin{array}{l}\text { This work } \\
\text { Adams et al. (2002) }\end{array}$ \\
\hline
\end{tabular}




\begin{tabular}{|c|c|c|c|c|c|}
\hline & & & & $50 \mathrm{mg} / \mathrm{L}:>90 \%$ & \\
\hline \multirow{3}{*}{ ETM } & PAC & Surface water & $20 \mathrm{mg} / \mathrm{L}$ & $90.6 \%, \mathrm{q}_{\mathrm{e}}: 235 \mathrm{ng} / \mathrm{mg}$ & This work \\
\hline & $\mathrm{BSA} / \mathrm{Fe}_{3} \mathrm{O}_{4}$ microspheres & Ultrapure water & $\begin{array}{l}\mathrm{BSA} / \mathrm{Fe}_{3} \mathrm{O}_{4} \text { microspheres }(200 \mathrm{mg}) \\
\text { added into } 100 \mathrm{~mL} \text { of solution }\end{array}$ & $98.98 \%$ & Zhang et al. (2013) \\
\hline & PAC & Surface water & $20 \mathrm{mg} / \mathrm{L}$ & $96.3 \%, \mathrm{q}_{\mathrm{e}}: 238 \mathrm{ng} / \mathrm{mg}$ & This work \\
\hline \multirow[t]{2}{*}{ CAP } & $\mathrm{BSA} / \mathrm{Fe}_{3} \mathrm{O}_{4}$ microspheres & Ultrapure water & $\begin{array}{l}\mathrm{BSA} / \mathrm{Fe}_{3} \mathrm{O}_{4} \text { microspheres }(200 \mathrm{mg}) \\
\text { added into } 100 \mathrm{~mL} \text { of solution }\end{array}$ & $96.4 \%$ & Zhang et al. (2013) \\
\hline & PAC & Surface water & $20 \mathrm{mg} / \mathrm{L}$ & $98.4 \%, \mathrm{q}_{\mathrm{e}}: 246 \mathrm{ng} / \mathrm{mg}$ & This work \\
\hline \multirow[t]{2}{*}{ PNG } & $\begin{array}{l}\text { Carbon nanoparticles made from } \\
\text { vine woo }\end{array}$ & Distilled water & $0.4 \mathrm{~g} / \mathrm{L}$ & $74-88 \%$ & $\begin{array}{l}\text { Pouretedal and Sadegh } \\
\text { (2014) }\end{array}$ \\
\hline & PAC & Surface water & $20 \mathrm{mg} / \mathrm{L}$ & $96.2 \%, \mathrm{q}_{\mathrm{e}}: 246 \mathrm{ng} / \mathrm{mg}$ & This work \\
\hline
\end{tabular}




\section{Conclusions}

This study investigated the removal of six groups of antibiotics (TCs, MCs, CPs, PNs, SAs, QNs) using PAC. The specific findings are as follows:

- PAC exhibited the high adsorption capacity for all selected antibiotics and these antibiotics were effectively removed from water.

- Based on the adsorption isotherms, the adsorption of antibiotics onto PAC was nonlinear and heterogeneous.

- NOMs in surface water exerted greater influence on the removal of SAs than others.

- The kinetics data suggested the adsorption process was governed by the pseudo-second-order reaction.

- It was observed that both the external surface adsorption and intra-particle diffusion were controlling factors in the antibiotic adsorption onto PAC.

It can be conclusively stated that PAC is an efficient and promising adsorbent for removing antibiotics from water.

\section{Acknowledgements}

The work was supported by National Natural Science Foundation (No.51308373 and No.51378338), and Tianjin Excellent College Teachers Funding Program (No.03010601). The authors are also grateful to the research collaboration between Tianjin Chenjian University, School of Environmental and Municipal Engineering and University of Technology, Sydney, Centre for Technology in Water and Wastewater, School of Civil and Environmental Engineering.

\section{References}

Adams C., ASCE M., Wang Y., Loftin K., Meyer M.. Removal of antibiotics from surface and distilled water in conventional water treatment processes. $\mathrm{J}$ Environ Eng 2002; 128: 253-260.

Ahmed M. B., Zhou J. L., Ngo H. H., Guo W.. Adsorptive removal of antibiotics from 
water and wastewater: Progress and challenges. Sci Total Environ 2015; 532: $112-126$

Ahmed M.J., Theydan S.K.. Fluoroquinolones antibiotics adsorption onto microporous activated carbon from lignocellulosic biomass by microwave pyrolysis. J Taiwan Inst Chem Eng 2014; 45:219-226.

Ando N., Matsui Y., Kurotobi R., Nakano Yu., Matsushita ., Ohno K.. Comparison of natural organic matter adsorption capacities of super-powdered activated carbon and powdered activated Carbon. Water Res 2010; 44: 4127-4136.

Aroua M.K., Leong S.P.P., Teo L.Y., Yin C.Y., Daud W.M.A.W.. Real-time determination of kinetics of adsorption of lead (II) onto palm shell-based activated carbon using ion selective electrode. Bioresour Technol 2008; 99: $5786-5792$.

Bajpai A.K., Rajpoot M., Mishra D.D.. Studies on the correlation between structure and adsorption of sulfonamide compounds. Colloid Surf. A: Physicochem. Eng. Asp. 2000; 168:193-205.

Białk-Bielin'ska A., Stolte S., Matzke M., Fabian'ska A., Maszkowska J., Kołodziejska M., et al.. Hydrolysis of sulphonamides in aqueous solutions. J Hazard Mater 2012; 221-222: 264-274.

Braschi I., Blasioli S., Gigli L., Gessa C.E., Alberti A., Martucci A.. Removal of sulfonamide antibiotics from water: Evidence of adsorption into an organophilic zeolite Y by its structural modifications. J Hazard Mater 2010; 178: 218-225.

Brown K.D., Kulis J., Thomson B., Chapman H.T., Mawhinney B.D.. Occurrence of antibiotics in hospital, residential, and dairy effluent, municipal wastewater, and the Rio Grande in New Mexico. Sci Total Environ 2006; 366: 772-783.

Calisto V., Ferreira C.I.A., Oliveira J.A.B.P., Otero M., Esteves V.I.. Adsorptive removal of pharmaceuticals from water by commercial and waste-based carbons. J Environ Manag 2015; $152: 83-90$.

Carabineiro S.A.C., Thavorn-amornsri T., Pereira M.F.R., Serp P., Figueiredo J.L.. Comparison between activated carbon, carbon xerogel and carbon nanotubes for 
the adsorption of the antibiotic ciprofloxacin. Catal Today 2012; 186: 29-34.

Chen, K., Zhou, J.. Occurrence and behavior of antibiotics in water and sediments from the Huangpu River, Shanghai, China. Chemosphere 2014; 95: 604-612.

Chen W.R., Huang C.H.. Adsorption and transformation of tetracycline antibiotics with aluminum oxide. Chemosphere 2010; 79: 779-785.

Constanzo S.D., Murby J., Bates J.. Ecosystem response to antibiotics entering the aquatic environment. Mar Pollut Bull 2005; 51(1-4): 218-223.

Gao Y., Li Y., Zhang L., Huang H., Hua J.J., Shah S.M., et al. Adsorption and removal of tetracycline antibiotics from aqueous solution by graphene oxide. J Colloid Interface Sci 2012; 368: 540-546.

Genç, N., Dogan, E.C.. Adsorption kinetics of the antibiotic ciprofloxacin on bentonite, activated carbon, zeolite, and pumice. Desalin Water Treat 2015; 53 (3):785-793.

Golovko O., Kumar V., Fedorova G., Randak T., Grabic R.. Seasonal changes in antibiotics, antidepressants/psychiatric drugs, antihistamines and lipid regulators in a wastewater treatment plant. Chemosphere 2014; 111: 418-426..

Ho Y.S. Citation review of Lagergren kinetic rate equationon adsorption reactions. Scientometrics 2004; 59(1): 171-177.

Ho Y.S. Review of second-order models for adsorption systems. J Hazard Mater B 2006; 136: 681-689.

Ho Y.S., McKAY G.. A comparison of chemisorption of kinetic models applied to pollutant removal on various sorbents. Process Saf Environ 1998; 76 (4): 332-340.

Jiang Y., Li M., Guo C., An D., Xu J., Zhang Y., et al. Distribution and ecological risk of antibiotics in a typical effluent-receiving river (Wangyang River) in north China. Chemosphere 2014; 112: 267-274.

Kim H., Hwang Y.S., Sharma V.K.. Adsorption of antibiotics and iopromide onto single-walled and multi-walled carbon nanotubes. Chem Eng J 2014; 255: 23-27.

Kim S.H., Shon H.K., Ngo H.H.. Adsorption characteristics of antibiotics trimethoprim on powdered and granular activated carbon. J Ind Eng Chem 2010; 
16: $344-349$.

Kolpin D.W., Furlong E.T., Meyer M.T., Thurman E.M., Zaugg S.D., Barber L.B., et al. Pharmaceuticals, hormones, and other organic wastewater constituents in US streams, 1999-2000: a national reconnaissance. Environ Sci Technol 2002; 36(6): $1202-1211$.

Lapworth D.J., Baran N., Stuart M.E., Ward R.S.. Emerging organic contaminants in groundwater: A review of sources, fate and occurrence. Environ Pollut 2012; 163: 287-303.

Li N., Zhang X.B., Wei W., Zhao X.H.. Occurrence, seasonal variation and risk assessment of antibiotics in the reservoirs in North China. Chemosphere 2014; 111:327-335.

Li W., Shi Y., Gao L., Liu J., Cai Y.. Occurrence and removal of antibiotics in a municipal wastewater reclamation plant in Beijing, China. Chemosphere 2013; 92: 435-444.

Loftin K.A., Adams C.D., Meyer M.T., Surampalli R.. Effects of ionic strength, semperature, and $\mathrm{pH}$ on degradation of selected antibiotics. J Environ Qual 2008; 37: 378-386.

Martins, A.C., Pezoti, O., Cazetta, A.L., Bedin, K.C., Yamazaki, D.A., Bandoch, G.F., et al. Removal of tetracycline by $\mathrm{NaOH}$-activated carbon produced from macadamia nut shells: kinetic and equilibrium studies. Chem Eng J 2015; 260: 291-299.

Martucci A., Cremonini M.A., Blasioli S., Gigli L., Gatti G., Marchese L., et al. Adsorption and reaction of sulfachloropyridazine sulfonamide antibiotic on a high silica mordenite: A structural and spectroscopic combined study. Micropor Mesopor Mat 2013; 170: 274-286.

Matsui Y., Yoshida T., Nakao S., Knappe D.R.U., Matsushita T.. Characteristics of competitive adsorption between 2-methylisoborneol and natural organic matter on superfine and conventionally sized powdered activated carbons. Water Res 2012; 46: 4741-4749. 
Méndez-Díaz J.D., Prados-Joya G., Rivera-Utrilla J., Leyva-Ramos R., Sánchez-Polo M., Ferro-García M.A., et al. Kinetic study of the adsorption of nitroimidazole antibiotics on activated carbons in aqueous phase. J Colloid Interface Sci 2010; 345: 481-490.

Nghiem L.D., Schäfer A.I., Elimelech, M.. Pharmaceutical retention mechanisms by nanofiltration membranes. Environ Sci Technol 2005; 39 (19): 7698-7705.

Ngumba E., Gachanja A., Tuhkanen T.. Occurrence of selected antibiotics and antiretroviral drugs in Nairobi River Basin, Kenya. Sci Total Environ 2016; 539: 206-213.

Pouliquen H., Delépée R., Larhantec-Verdier M., Morvan M., Bris H.L.. Comparative hydrolysis and photolysis of four antibacterial agents (oxytetracycline oxolinic acid, flumequine and florfenicol) in deionised water, freshwater and seawater under abiotic conditions. Aquaculture 2007; 262: 23-28

Pouretedal, H., Sadegh, N.. Effective removal of amoxicillin, cephalexin, tetracycline and penicillin $\mathrm{G}$ from aqueous solutions using activated carbon nanoparticles prepared from vine wood. J Water Process Eng 2014; 1: 64-73.

Radjenovic' J., Petrovic' M., Ventura F., Barcelo' D.. Rejection of pharmaceuticals in nanofiltration and reverse osmosis membrane drinking water treatment. Water Res 2008; 42: 3601-3610.

Rauthula M.S., Srivastava V.C..Studies on adsorption/desorption of nitrobenzene and humic acid onto/from activated carbon. Chem Eng J 2011; 168: 35-43.

Rivera-Utrilla J., Prados-Joya G., Sánchez-Polo M., Ferro-García M.A., Bautista-Toledo I.. Removal of nitroimidazole antibiotics from aqueous solution by adsorption/bioadsorption on activated carbon. J Hazard Mater 2009; 170: 298-305.

Rivera-Utrilla J., Sánchez-Polo M., Ferro-García M.Á., Prados-Joya G., Ocampo-Pérez R.. Pharmaceuticals as emerging contaminants and their removal from water. A review. Chemosphere 2013; 93: 1268-1287.

Sacher F., Lange F.T., Brauch H.J., Blankenhorn I.. Pharmaceuticals in groundwaters 
Analytical methods and results of a monitoring program in Baden-Württemberg, Germany. J Chromatogr A 2001; 938: 199-210.

Snyder S.A., Adham S., Redding A.M., Cannon F.S., DeCarolis J., Oppenheimer J., et al. Role of membranes and activated carbon in the removal of endocrine disruptors and pharmaceuticals. Desalination 2007; 202: 156-181.

Tian, Y., Gao, B., Morales, V.L., Chen, H., Wang, Y., Li, H.. Removal of sulfamethoxazole and sulfapyridine by carbon nanotubes in fixed-bed columns. Chemosphere 2013; 90 (10): 2597-2605.

Watkinson A.J., Murby J., Costanzo S.D.. Removal of antibiotics in conventional and advanced wastewater treatment: Implications for environmental discharge and wastewater recycling. Water Res 2007; 41: 4164 -4176.

Watkinson A.J., Murby E.J., Kolpin D.W., Costanzo S.D.. The occurrence of antibiotics in an urban watershed: From wastewater to drinking water. Sci Total Environ 2009; 407: 2711-2723.

Weber W.J., Morris J.C., Sanit J.. Kinetics of adsorption on carbon from solution. Eng Div Am Soc Civil Eng 1963; 89: 31-60.

Westerhoff P., Yoon Y., Snyder S., Wert E.. Fate of endocrine-disruptor, pharmaceutical, and personal care product chemicals during simulated drinking water treatment processes. Environ Sci Technol 2005; 39 (17): 6649-6663.

Wu Q.F., Li Z.H., Hong H.L.. Adsorption of the quinolone antibiotic nalidixic acid onto montmorillonite and kaolinite. Appl Clay Sci 2013, 74, 66-73.

Ye Z.Q., Weinberg H.S., Meyer M.T.. Trace Analysis of Trimethoprim and Sulfonamide, Macrolide, Quinolone, and Tetracycline Antibiotics in Chlorinated Drinking Water Using Liquid Chromatography Electrospray Tandem Mass Spectrometry. Anal Chem 2007; 79(3): 1135-1144.

Xu L.C., Dai J.D., Pan J., Li X.X., Huo P.W., Yan Y.S., et al. Performance of rattle-type magnetic mesoporous silica spheres in the adsorption of single and binary antibiotics. Chem Eng J 2011; 174: 221-230.

Yiruhan, Wang Q.J., Mo C.H., Li Y.W., Gao P, Tai Y.P., et al. Determination of four 
fluoroquinolone antibiotics in tap water in Guangzhou and Macao. Environ Pollut 2010; 158(7): 2350-2358.

Zhang B.L., Zhang H.P., Li X.J., Lei X.F., Li C.M., Yin D.Z., et al. Synthesis of $\mathrm{BSA} / \mathrm{Fe}_{3} \mathrm{O}_{4}$ magnetic composite microspheres for adsorption of antibiotics. Mater Sci and Eng C 2013; 33:4401-4408. 